\title{
Preparative Synthesis \\ of Furfural Diethyl Acetal Through \\ the Direct Interaction of the Alcohol and Aldehyde
}

\author{
Mikhail Yu. Chernyak ${ }^{a}$, Valery E. Tarabanko*a,b, \\ Andrey A. Morosovi and Alexander A. Kondrasenko ${ }^{a}$ \\ ${ }^{a}$ Institute of Chemistry and Chemical Technology SB RAS \\ FRC "Krasnoyarsk Science Center SB RAS" \\ 50/24 Akademgorodok, Krasnoyarsk, 660036, Russia \\ ${ }^{b}$ Siberian Federal University \\ 79 Svobodny, Krasnoyarsk, 660041, Russia
}

Received 12.01.2016, received in revised form 26.03.2016, accepted 09.05.2016

\begin{abstract}
A possibility of the furfural diethyl acetal preparation by direct interaction of the aldehyde and a slight excess of ethanol with high selectivity and preparative yield of $70 \%$ was demonstrated. To shift the acetalization equilibrium the water vapour was absorbed by calcium oxide from gas phase. The acetalization process suggested is accelerated by the acid catalysts.
\end{abstract}

Keywords: furfural, furfural diethyl acetal, calcium oxide, diffusion, equilibrium, catalysis, biofuels.

DOI: 10.17516/1998-2836-2016-9-2-146-151.

(C) Siberian Federal University. All rights reserved

* Corresponding author E-mail address: veta@icct.ru 


\title{
Препаративный синтез
}

\section{диэтилацеталя фурфурола \\ прямым взаимодействием спирта и альдегида}

\author{
М.Ю. Черняк ${ }^{\mathrm{a}}$, В.Е. Тарабанько ${ }^{\mathrm{a}, \tilde{\sigma}}$, \\ А.А. Морозов ${ }^{\text {, }}$ А.А. Кондрасенко ${ }^{\mathrm{a}}$ \\ ${ }^{a}$ Институт химии и химической технологии СО РАН \\ ФИЦ «Красноярский научный иентр СО РАН» \\ Россия, 660036, Красноярск, Академгородок, 50/24 \\ ${ }^{6}$ Сибирский федеральный университет \\ Россия, 660041, Красноярск, пр. Свободный, 79
}

\begin{abstract}
Продемонстрирована возможность получения диэтилацеталя фурфурола прямым взаимодействием незначительного избытка этанола $c$ альдегидом $c$ высокой селективностью и препаративным выходом до $70 \%$. Смещение равновесия ацетализации достигается удалением паров воды оксидом кальция из газовой фазы над реакиионной смесью. Разработанный процесс ацетализации протекает как в присутствии кислотных катализаторов, так и с меньшей скоростью без них.
\end{abstract}

Ключевые слова: фурфурол, диэтилачеталь фурфурола, диффузия, катализ, равновесие, биотоплива.

\section{Introduction}

A main way to reduce dependence from hydrocarbons derived from crude oil and to improve the characteristics of the fuel for gasoline (diesel) engines is to apply biomass-derived oxygenated compounds.

Ethers are widely used as the fuel components. Methyl tert-butyl ether (MTBE), tert-amyl methyl ether (TAME) and more ecologically benign ethyl tert-butyl ether (ETBE), are important oxygenated compounds used at the commercial scale [1]. Acetals and ketals, which may refer as ethers, are also often used as an important oxygenates [2], which boost the cetane number of diesel fuel and reduce toxic exhaust emissions [3].

Furfural (FUR) is a large scale product of the hydrolysis and dehydration of pentose carbohydrates contained in lignocellulosics. Furfural derived liquid biofuels are studied and developed in recent decades. Furfural derivatives, 2-methylfuran, furfuryl alcohol, and its ethers have high octane numbers $(\mathrm{ON})$ and they are suitable compounds for blending gasoline $[4,5]$.

Alkyl furfuryl ethers can be obtained by the alcohol etherification of furfuryl alcohol in the presence of acid catalysts. Thus, when the reaction was performed in dilute acids or by the heterogeneous catalysts the selectivity reached only approximately 30-50\% at different conversions [6]. The formation of alkyl furfuryl ethers was accompanied by producing heavy byproducts. 
Hydrogenation of furfural acetals is another possible approach to produce the alkyl furfuryl ethers [5], and the effective synthetic methods to produce the acetals are required for the developing this pathway.

Acetalization can be carried out at least by two ways. First is the application of active and expensive alkylating agent, for example, triethyl orthoformate [7], and the second is to use catalysts and a great excess of inexpensive primary alcohols [8]. To decrease the alcohol excess one should apply dehydrating agents or other ways to remove water and to shift the reaction equilibrium to the right:

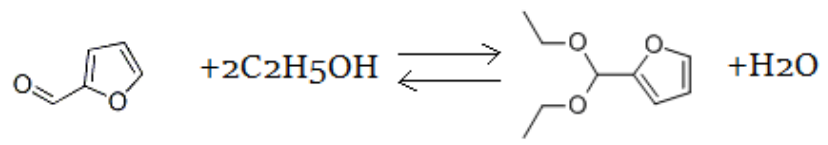

Removal of water from ethanol solutions is a complicated process. A well-known commercial example is the purification of ethanol to an anhydrous product using the benzene-water azeotrope rectification. This process requires rather great efficiency of rectifying columns (app. 40 theoretical plates) [9], and there is no reasons to expect that removing water from the mixture (1) will be the simpler process.

Possibility of application of dehydrating agents for the acetalization equilibrium shift almost did not study due to important disadvantages such as great acidity $\left(\mathrm{P}_{2} \mathrm{O}_{5}\right)$, low capacity $\left(\mathrm{SiO}_{2}\right)$ or low reactivity to water molecules $\left(\mathrm{Na}_{2} \mathrm{SO}_{4}\right)$.

The goal of the present work is to develop the preparative method of the furfural diethyl acetal (FDEA) synthesis by the direct interaction of furfural with a little excess of ethanol at room temperature.

\section{Experimental}

All the following chemicals were purchased from the chemical companies and directly used without any purification: furfural (98\%, Acros Organics), calcium oxide (CaO) (technical grade), cation exchange resin KU-2-8 (strongly acidic resin, sulfonated polystyrene, GOST 20298-74 $\left(\mathrm{H}^{+}\right)$). To dry the ethanol pure (pharma grade, $96 \%$ ) it was pretreated with calcium oxide for $12 \mathrm{~h}$ and distilled over calcium oxide at atmospheric pressure.

The reaction mixture of ethanol and furfural $(411 \mathrm{~g})$ in a glass crystallizer of appropriate volume was placed in a desiccator, and its bottom was filled with $300 \mathrm{~g}$ of the calcium oxide stones. The molar ratio of ethanol : furfural was 3:1. The experiments were carried out at room temperature for three months. The calcium hydroxide formed was replaced with the fresh portions of calcium oxide after 30 and 60 days.

The catalytic experiments were carried out similarly in the presence of the cation exchange resin, and the mass ratio of the resin to reaction mixture was of 1:4 [10].

Analysis of the acetalization reaction was carried out by ${ }^{1} \mathrm{H}$ NMR (Nuclear Magnetic Resonance spectrometer Bruker Avance III $600 \mathrm{MHz}$ ) of the Center for collective use of the Krasnoyarsk Scientific Center of the Russian Academy of Sciences.

Furfural diethyl acetal obtained was washed with water from unreacted furfural and ethanol. The organic phase was dried with calcinated potassium carbonate and distilled under reduced pressure (1820 Torr), boiling point is of $83-85^{\circ} \mathrm{C}$. 
Furfural diethyl acetal: ${ }^{1} \mathrm{H}$ NMR $\left(600 \mathrm{MHz}, \mathrm{CDCl}_{3}\right), \delta 1.16-1.18(\mathrm{~m}, 6 \mathrm{H}), 3.54-3.62(\mathrm{~m}, 4 \mathrm{H}), 5.49$ (c, 1H), $6.29(\mathrm{dd}, 1 \mathrm{H}), 6.35(\mathrm{~m}, 1 \mathrm{H}), 7.34(\mathrm{dd}, 1 \mathrm{H})$.

\section{Results and discussion}

First we estimated the equilibrium constant of the acetalization reaction (1) using ${ }^{1} \mathrm{H}$ NMR data of the reaction mixture, and it was equel to 0.04 approximately. This means that to attain the depth of acetalization of $95 \%$ one should either to increase ethanol concentration up to 50-100 times more than stoichiometry ratio [8], or water content in the system should be decreased to the value less than 1 mol. \%.

To shift reaction equilibrium (1) we used calcium oxide as a dehydrating agent. Direct adding $\mathrm{CaO}$ to the reaction mixture does not shift the acetalization equilibrium (1) because the alkaline medium breaks the process [11]. For this reason, we used calcium oxide to remove water from the vapor phase above the liquid reaction mass, and this approach gave positive results. Under these conditions, the rate of acetalization may be limited by the rates of diffusion and mass transfer of water vapor from the reaction mass to the surface of calcium oxide and the process may be very slow. Indeed, non-catalytic process proceeds during three months (Fig. 1).

The weight loss of the reaction mixture due to removing water and ethanol evaporation was $185 \mathrm{~g}$ (45 wt. \%). The remaining reaction mixture (266 g) contained $16 \mathrm{~g}(6 \mathrm{wt}$. \%) of unreacted furfural. 220 $\mathrm{g}$ of furfural diethyl acetal were obtained by fractional distillation, and the product yield corresponded to a value of 70-73\% of theory. Similar analytical yield of FDEA (determined by GLC) was obtained in the acetalization of furfural catalyzed by H-USY zeolites without removing water, but with a great excess of ethanol (100 mol / mol furfural) [8].

Adding the cation exchange resin (KU-2-8, 1:4 by weight of the reaction mass) into the reaction mass under similar conditions accelerated the process: furfural diethyl acetal proton signals $(2-3 \%$ of the starting furfural signal) were recorded by NMR after $4 \mathrm{~h}$ of the experiment. After 7 days the furfural conversion exceeded $50 \%$. Almost complete acetalization were attained after 3 weeks (the residual concentration of furfural decreased down to a level of 3-5\%, Fig. 1). Preparative yield of the target product of 70 stoichiometric $\%$ was attained in the catalytic experiments.

The catalyst accelerates principally (by a factor of 10-20 times) the acetalization process (Fig. 1), and this fact indicates that without the resin the process proceeds as a kinetically controlled one. Accelerating the process by the catalyst transforms it to a diffusion-controlled reaction. In this situation, a further acceleration of the catalytic acetalization can be attained by intensifying the mass transfer in the gas and liquid phases, i.e. mixing each of the phases. Such a development of the process can accelerate it up to the known parameters of the catalytic processes described in [8] (3-4 hours).

Another possible way to intensify the water removal from the reaction mass during the acetalization is the use of Soxhlet apparatus, in which the filter paper cartridges with calcium oxide were placed into a thimble to absorb water. The reaction mass (and catalyst) were loaded into the still pot under the thimble. The target product yields of $15-20 \%$ of theory were obtained after 50 hours of processing, and addition of cation exchange resin into the reaction mass did not change the maximum product yield.

Inhibition of the process in Soxhlet apparatus is probably originated from solubility of calcium hydroxide or ethoxide in ethanol and breaking the acetalization reaction in alkaline media. Indeed, calcium ions are qualitatively detected in the reaction mixture. 


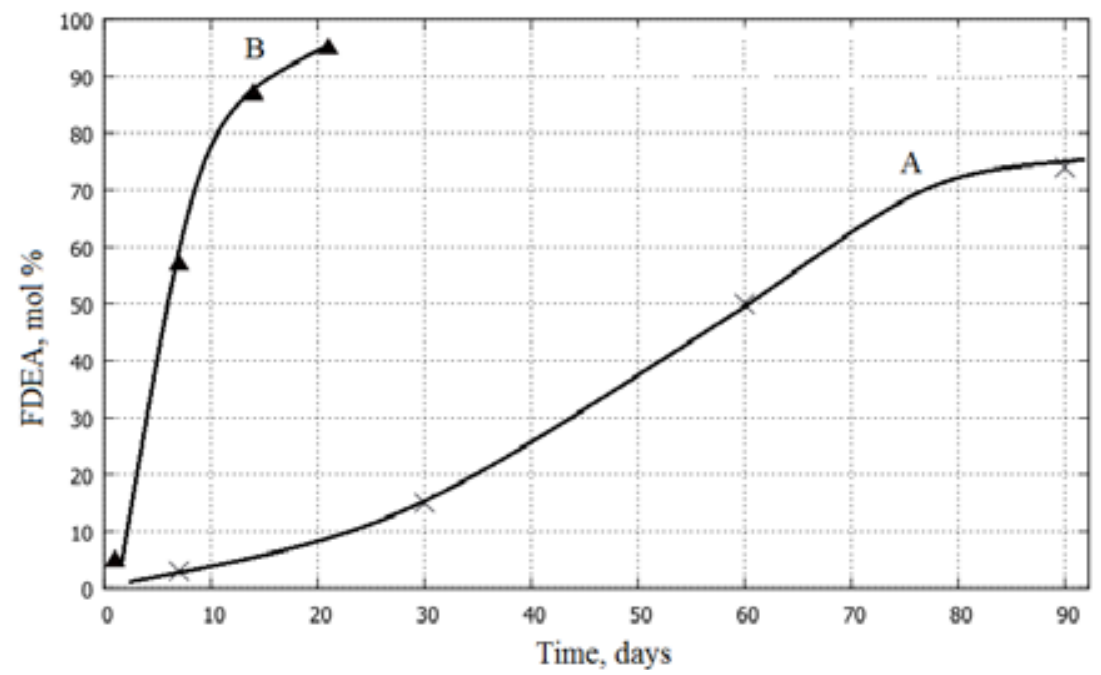

Fig. 1. The formation of furfural diethyl acetal in the reaction mixture. Ethanol : furfural is of $3: 1,25{ }^{\circ} \mathrm{C}$. A - without catalyst; B - with the cation exchange resin as the catalyst, the mass ratio of the resin to reaction mixture is of 1:4

Similarly, ammonium chloride and sodium hydrosulfate were tested as the possible acetalization catalysts. Ammonium chloride showed no catalytic activity. High acidity of sodium hydrosulfate led to a rezinification of furfural.

\section{Conclusion}

The preparative method of furfural diethyl acetal synthesis based on consumption of water vapor above the reaction mass with calcium oxide placed in the gas phase is developed. The process can be carried out in the presence of catalysts or without it. The process is characterized by high selectivity and preparative yield (95 and $70 \%$, correspondingly) and does not require large excesses of ethanol or expensive alkylating reagents.

The suggested process outperforms the possible method of synthesis of the acetal with water removal by rectification, because the latter is more complicated and requires much heat energy input. Long duration of the process can be decreased by the mass transfer intensification of water between the reaction mass and $\mathrm{CaO}$ surface.

\section{References}

1. Maximov A.L., Nekhaev A.I. and Ramazanov D.N. Ethers and Acetals, Promising Petrochemicals from Renewable Sources // J. Petroleum chemistry, 2015, Vol. 55, No 1, p. 1-21.

2. Maximov A.L. et all. Preparation of High-Octane Oxygenate Fuel Components from PlantDerived Polyols // J. Petroleum chemistry, 2011, Vol. 51, No 1, pp. 61-69.

3. Viviana M. T. M. Silva, Carla S. M. Pereira, and Alírio E. Rodrigues. Synthesis of diethylacetal: thermodynamic and kinetic studies // Chemical Engineering Science, 2001, pp. 1255 - 1263.

4. Simakova I.L., Tarabanko V.E., Chernyak M.Yu., Kondrasenko A.A., Simonov M.N. Catalytic hydrogenation of furfural in alcoholic media // Journal of Siberian Federal University. Chemistry 4, 2015, Vol. 8, pp. 482-490. (In Russ.) 
5. Tarabanko V.E., Chernyak M.Yu., Simakova I.L., Kaigorodov K.L., Bezborodov Yu.N., Orlovskay N.F. Antiknock Properties of Furfural Derivatives // Russian Journal of Applied Chemistry, 2015, Vol. 88, No. 11, pp. 1778-1782.

6. Lange J.-P., Evert van der Heide, Jeroen van Buijtenen, Price R. Furfural - a promising platform for lignocellulosic biofuels // ChemSusChem. 2012, Vol. 5, pp. 150 - 166.

7. Organikum: Organisch-chemisches Grundpraktikum / H. Becker, W. Berger. Vol. 1, 2. 22. Aufl., Wiley/VCH , 1992. 342 p.

8. Juan Miguel Rubio-Caballero, Shunmugavel Saravanamurugan, Pedro Maireles-Torres, Anders Riisager. Acetalization of furfural with zeolites under benign reaction conditions // Catalysis Today. 2014. PP. 233-236.

9. Tsygankov P.S., Tsygankov S.P. Guidelines for alcohol distillation - M.: Pishchepromizdat, $2001-400$ p. (In Russ.)

10. Zelikman Z.I., Kulnevich V.G. Kinetics of furfural acetalization with an ion-exchange resin KU-2. Ion exchange and resins. Digest of articles. L .: «Nauka», 1970, p. 316-320. (In Russ.)

11. March J. Advanced Organic Chemistry: Reactions, Mechanisms, and Structure (6th ed.) John Wiley \& Sons, Inc., Hoboken, New Jersey. 2007. - 2080 p. 